\title{
Tinjauan Yuridis Terhadap Kewenangan MPR Dalam Melakukan Perubahan Undang-Undang Dasar
}

\author{
Munif Rochmawanto *) \\ ${ }^{*)}$ Dosen Fakultas Hukum Universitas Islam Lamongan
}

\begin{abstract}
In a lawful country, the existence of constituent is one of the most important requirements to control a country. Hence, it is also required for Indonesia; which had put its society life rules fully in a constituent (UUD 1945). By far, Indonesia has faith that the importance of a constituent's existence will take effect for a greater life in nation society's needs.

The change in a constituent or UUD in a country, for instance, will be done by a competent national bureau. In Indonesia, such competency is obtained by Majelis Permusyawaratan Rakyat (MPR). Meanwhile, the reformation era takes its role in year 1998, and then MPR held the court to discuss about the change in UUD 1945 for some times ahead; at 19th of October 1999, the first change had done, at 18th of August 2000, the second change had done, and also, at 10th of November, the third change had done, and finally at 10th of August 2002, the fourth change had done too.
\end{abstract}

\section{Keywords: Juridic observation, MPR Rights, The Change in UUD}

\section{Pendahuluan}

Dalam suatu negara hukum, keberadaan konstitusi merupakan prasyarat penting dalam mengatur tatanan kenegaraan. Demikian halnya dengan negara Indonesia yang menuangkan pengaturan kehidupan kenegaraannya dalam sebuah konstitusi (UUD 1945). Dengan ini, Indonesia meyakini sepenuhnya arti penting keberadaan sebuah konstitusi bagi kelancaran kehidupan berbangsa dan bernegara.

Menurut Sri Soemantri, konstitusi sebagai sebuah dokumen formal mengandung substansi: ${ }^{33}$

1. Hasil perjuangan politik bangsa di waktu lampau.

2. Pandangan tokoh bangsa yang hendak diwujudkan baik untuk waktu sekarang maupun untuk masa yang akan datang.

3. Suatu keinginan (kehendak) yang mana perkembangan kehidupan ketatanegaraan bangsa hendak dipimpin.

4. Tingkat-tingkat tertinggi perkembangan ketatanegaraan bangsa.

Demikian pentingnya sebuah konstitusi bagi kehidupan kenegaraan suatu bangsa sehingga ditempatkan pada posisi tertinggi dalam tata urutan peraturan perundang - undangan tertulis di Indonesia. Sebagai suatu peraturan perundang - undangan yang tertinggi dalam sebuah negara, yang kemudian memberikan jiwa kepada peraturan - peraturan yang lebih rendah di bawahnya, sehingga substansi pengaturan yang ada di dalam konstitusi tersebut harus mampu menjamin terselenggaranya sistem ketatanegaraan Indonesia.

Bertolak dari keharusan untuk memberikan jaminan terhadap penyelenggaraan kehidupan ketatanegaraan di Indonesia, maka sebuah konstitusi harus memiliki kemampuan untuk dirubah. Tanpa adanya kemampuan tersebut tidak mungkin dijamin adanya sebuah konsitusi yang mampu mengikuti perkembangan masyarakat. Karena masyarakat terus berkembang dan berdampak terhadap penerapan aturan yang terdapat dalam substansi UUD, maka seharusnyalah suatu konstitusi memiliki sebuah kekuatan untuk merubah dirinya.

Perubahan terhadap sebuah konstitusi atau UUD dalam suatu negara tentunya dilakukan oleh sebuah lembaga negara yang berkompeten. Di Indonesia kompetensi untuk itu dimiliki oleh Majelis Permusyawaratan Rakyat (MPR). Sebelum adanya perubahan. UUD 1945, kewenangan perubahan UUD yang dilakukan oleh MPR, belum pernah dipergunakan. Bahkan MPR memiliki kebulatan tekad

\footnotetext{
${ }^{33}$ Sri Soemantri, UUD 1945 Kedudukan dan Aspek-aspek Perubahannya, Unpad Press, Bandung, cetakan pertama, 2002, hal. 4
} 
untuk mempertahankan UUD 1945 dan tidak berkehendak melakukan perubahan terhadapnya serta akan melaksanakan secara murni dan konsekuen, seperti yang tercantum dalam Pasal 115 TAP MPR NO. 1/MPR/1978 tentang Peraturan Tata Tertib MPR.

Dalam pada itu, dalam lampiran Ketetapan MPRS No. XX/MPRS/1966 tentang Memorandum DPR-GR mengenai sumber tertib hukum RI dan Tata Urutan Peraturan Perundang-undangan RI, bagian 1, No. 3 sub c, dinyatakan bahwa:".... Pembukaan UUD 1945 tidak dapat diubah oleh siapapun juga, termasuk MPR hasil pemilihan Umum.

Landasan yang dipergunakan untuk tidak melakukan suatu perubahan terhadap UUD 1945 dalam kedua ketetapan MPR tersebut, jelas sangat bertentangan dengan ketentuan Pasal 37 UUD 1945. Dalam tata hirarki peraturan perundang-undangan ketetapan MPR berada dan berposisi dalam suatu tingkatan yang berada di bawah UUD 1945. Oleh karena itu, maka tidak ada alasan bagi MPR melalui ketetapannya untuk tidak melakukan perubahan terhadap UUD 1945.

Seiring dengan itu, pada era reformasi yang bergulir pada tahun 1998, kemudian MPR bersidang untuk membahas tentang perubahan UUD 1945 yang berturut-turut dilakukan pada sidang tanggal 19 Oktober 1999 dilakukan perubahan pertama terhadap UUD 1945, tanggal 18 Agustus 2000 dilakukan perubahan kedua, 10 November 2001 dilakukan perubahan ketiga, 10 Agusutus 2002 dilakukan perubahan keempat.

Setelah terjadinya empat kali perubahan terhadap UUD 1945 mungkinkah terjadi perubahan selanjutnya oleh MPR?. Kemungkinan tersebut sangat terbuka sekali, apalagi kalau dilihat beberapa kali perubahan yang telah dilakukan oleh MPR. Selain itu ketentuan tentang kewenangan MPR untuk menetapkan dan merubah UUD 1945 sebagaimana diatur dalam perubahan ketiga tanggal 10 November 2001 Pasal 3 ayat (1) junto Pasal 37 perubahan keempat tanggal 10 Agustus 2002, bukan tidak mungkin jika terjadi perubahan kelima, keenam dan seterusnya terhadap UUD 1945 oleh MPR.

Adapun cara yang dapat digunakan untuk mengubah Undang-undang Dasar atau Konstitusi melalui jalan penafsiran, menurut K.C. Wheare ada empat macam cara, yaitu melalui : ${ }^{34}$

1. Beberapa kekuatan yang bersifat primer (some primary forces)

2. Perubahan yang diatur dalam konstitusi (formal amandement)

3. Penafsiran secara hukum (judicial interpretation)

4. Kebiasaan dan kebiasaan yang terdapat dalam bidang ketatanegaraan (usage and convention)

Dalam ketentuan UUD 1945 menyediakan satu cara untuk melakukan suatu perubahan UUD. Pasal 37 UUD 1945 menyebutkan :

1. Untuk mengubah UUD sekurang-kurangnya $2 / 3$ daripada jumlah anggota MPR harus hadir.

2. Putusan diambil dengan persetujuan sekurang-kurangnya $2 / 3$ daripada jumlah anggota yang hadir.

Sedangkan dalam perubahan keempat pasal 37 UUD 1945, disebutkan cara-cara untuk melakukan perubahan terhadap UUD adalah sebagai berikut :

1. Usul perubahan pasal-pasal Undang-undang Dasar dapat diagendakan dalam sidang Majelis Permusyawaratan Rakyat apabila diajukan oleh sekurang-kurangnya 1/3 dari jumlah anggota MPR.

2. Setiap usul perubahan pasal-pasal Undang-undang Dasar diajukan secara tertulis dan ditunjukkan dengan jelas bagian yang diusulkan untuk diubah beserta alasannya.

3. Untuk mengubah pasal-pasal Undang-undang Dasar, sidang MPR dihadiri oleh sekurangkurangnya 2/3 dari jumlah anggota Majelis Permusyawaratan Rakyat.

4. Putusan untuk mengubah pasal-pasal Undang-undang Dasar dilakukan dengan persetujuan sekurang-kurangnya lima puluh persen ditambah satu anggota dari seluruh anggota Majelis Permusyawaratan Rakyat.

5. Khusus mengenai bentuk Negara Kesatuan Republik Indonesia tidak dapat dilakukan perubahan.

Keberadaan konstitusi dalam setiap negara yang mana di dalamnya memuat aturan-aturan serta ketentuan-ketentuan pokok atau dasar tentang sistem ketatanegaraan, yang menjadi dasar serta

${ }^{34}$ Dahlan Thaib, Jazimhamidi, Ni'matul Huda, Teori dan Hukum Konstitusi, PT. Raja Grafindo Persada, Jakarta, cetakan kedua, 2001, hal. 76 
pedoman penyelenggaraan sistem ketatanegaraan negara yang bersangkutan. Oleh karena itu, apakah setiap dalam proses penyelenggaraan negara telah memenuhi unsur-unsur dari sebagai suatu konsep kesadaran bernegara yang seutuhnya seperti berkedaulatan rakyat, negara hukum, yang selama ini telah dilaksanakan, dapat menjadi suatu bahan pertimbangan dan pemikiran oleh MPR untuk perubahan Undang-undang Dasar, khususnya Undang-undang Dasar 1945.

Berdasarkan latar belakang pemikiran sebagaimana tersebut diatas,berikut ini akan dicoba dibahas beberapa persoalan sebagai berikut :

1. Bagaimana kewenangan MPR untuk melakukan perubahan Undang-Undang Dasar Republik Indonesia sebelum dan sesudah amandemen UUD 1945?

2. Bagaimanakah hubungan antara kewenangan MPR untuk melakukan perubahan UUD dengan kedaulatan rakyat?

\section{Konsep Teori}

\section{Pengertian Negara Hukum Dan Demokrasi}

Pengertian negara hukum sebenarnya sudah lama ada. Dalam perpustakaan Yunani Kuno sudah disinggung tipe negara yang ideal yang dikemukakan oleh Plato dan Aristoteles. Dalam filsafatnya, keduanya menyinggung angan-angan manusia yang berkorespondensi dengan dunia yang mutlak yang disebut: cita-cita untuk mengejar kebenaran; cita-cita untuk mengejar kesusilaan; cita-cita untuk mengejar keindahan; dan cita-cita untuk mengejar keadilan. ${ }^{35}$

Menurut Aristoteles, suatu negara yang baik ialah negara yang diperintah dengan konstitusi dan berkedaulatan hukum. Artistoteles menyatakan: "Aturan konstitusional dalam negara berkaitan secara erat, juga dengan pertanyaan kembali apakah lebih baik diatur oleh manusia atau hukum terbaik, selama suatu pemerintahan menurut hukum, oleh sebab itu supremasi hukum diterima oleh Aristoteles sebagai tanda negara yang baik dan bukan semata-mata sebagai keperluan yang tidak layak". ${ }^{36}$

Aristoteles mengemukakan tiga unsur dari pemerintahan berkonstitusi, yaitu Pertama; pemerintah dilaksanakan untuk kepentingan umum. Kedua; pemerintahan dilaksanakan menurut hukum yang berdasarkan ketentuan-ketentuan umum, bukan hukum yang dibatasi secara sewenangwenang yang menyampingkan konvensi dan konstitusi, ketiga; pemerintahan berkonstitusi berarti pemerintahan yang dilaksanakan atas kehendak rakyat, bukan berupa paksaan tekanan seperti dilaksanakan pemerintahan despotis. ${ }^{37}$

Salah satu ciri dari negara hukum adalah adanya legalitas, ini dimaksudkan bahwa segala tindakan seluruh warga negara, baik rakyat maupun pemerintah haruslah dibenarkan oleh hukum. Di Indonesia berbagai macam peraturan untuk segala tindakan sudah ada ketentuannya, sehingga untuk setiap tindakan itu harus sah menurut aturan hukum yang telah ada. Untuk mengamankan ketentuan tersebut maka di Indonesia telah dibentuk berbagai badan peradilan untuk memberi pemutusan (peradilan) terhadap hal-hal yang dianggap melakukan hal-hal yang tidak dibenarkan oleh hukum. ${ }^{38}$

Kalau konsep negara hukum Eropa Kontinental dan konsep negara Anglo Saxon di dasarkan pada paham liberal individualistis, maka konsep negara hukum Indonesia didasarkan pada pandangan hidup bangsa Indonesia, Pancasila. Perbedaannya dalam hal ini terutama terletak pada masalah kedudukan individu terhadap masyarakat dan hak serta kewajiban individu terhadap masyarakat. Perbedaan ini terutama karena pengaruh pandangan hidup serta latar belakang sejarah bangsa Indonesia. Karena itu konsep negara hukum Indonesia pun dengan sendirinya juga berbeda dengan konsep negara hukum liberal. ${ }^{39}$.

Dalam suatu negara yang berdasarkan pada prinsip demokrasi, rakyat adalah pemegang dan pemilik kedaulatan sepenuhnya. Dahlan Thaib, dalam bukunya yang berjudul "Kedaulatan Rakyat, Negara Hukum dan Konstitusi", menyebutkan, asas kedaulatan rakyat atau paham demokrasi mengadung 2 (dua ) arti: pertama, demokrasi yang berkaitan dengan sistem pemerintahan atau

\footnotetext{
${ }^{35}$ Moh. Kusnardi dan Bintan Saragih, Ilmu Negara, Gaya Media Pratama, Jakarta, 1988,

hal 14

${ }^{36}$ Dahlan Thaib, Kedaulatan ..... Op.cit. hal 22

${ }^{37}$ Ibid

${ }^{38}$ Moh. Mahfud, MD, Dasar dan Struktur Ketatanegaraan Indonesia, UII Press, Yogyakarta, 1993, hal 97

${ }^{39}$ Azhary, Negara Hukum Indonesia, Analisis Yuridis Normatif tentang Unsur-unsurnya, UI Press, Jakarta, 1995, hal 116
} 
bagaimana caranya rakyat diikutsertakan dalam penyelenggaraan pemerintahan, dan yang kedua, demokrasi sebagai asas yang dipengaruhi keadaan kultural, historis, suatu bangsa sehingga muncul istilah demokrasi konstitusional, demokrasi rakyat dan demokrasi Pancasila. Yang jelas bahwa di setiap negara dan setiap pemerintahan modern pada akhirnya akan berbicara tentang rakyat. Dalam proses bernegara rakyat sering dianggap hulu dan sekaligus muaranya. Rakyat adalah titik sentral karena rakyat di suatu negara pada hakekatnya adalah pemegang kedaulatan, artinya rakyat menjadi sumber kekuasaan. ${ }^{40}$

Dengan demikian kedaulatan rakyat meyakini bahwa yang sesungguhnya berdaulat dalam setiap negara adalah rakyat. Kehendak rakyat merupakan satu-satunya sumber kekuasaan bagi setiap pemerintah.

Kedaulatan menurut ajaran J.J. Rosseau dinyatakan dalam bentuk pernyataan kehendak, sehingga kedaulatan rakyat itu diwujudkan dalam pernyataan rakyat untuk menyampaikan kehendaknya. Kehendak rakyat itu disampaikan dalam dua cara yaitu Kehendak rakyat seluruhnya yang dinamakan "volonte de tous", dan Kehendak sebagian besar rakyat yang dinamakan "volonte generale". Volonte de tous hanya dipergunakan oleh rakyat seluruhnya sekali saja waktu negara hendak dibentuk melalui perjanjian masyarakat. Maksud volonte de tous ini untuk memberi dasar agar supaya negara dapat berdiri abadi, karena ini merupakan kebulatan kehendak, dan jika negara itu sudah berdiri, pernyataan setuju tidak bisa ditarik kembali. Sedangkan volonte generale dinyatakan setelah negara berdiri, yaitu dengan pernyataan kehendak rakyat melalui suara terbanyak. ${ }^{41}$

Bangsa Indonesia sebagai suatu bangsa yang mempunyai falsafah hidup sendiri yang memberi ciri khusus pada kehidupan berbangsa dan bernegara, maka dalam melaksanakan asas kedaulatan rakyat dalam berkehidupan bernegara tidak terlepas dari falsafah yang dianut oleh bangsa Indonesia yang bersumber dan dijiwai oleh dasar falsafah negara Pancasila: Pada Ketuhanan Yang Maha Esa, kemanusiaan yang adil dan beradab, persatuan Indonesia, kerakyatan yang dipimpin oleh hikmah kebijaksanaan dalam dalam permusyawaratan/perwakilan dan untuk mewujudkan keadilan sosial bagi seluruh rakyat Indonesia. ${ }^{42}$

Demokrasi Pancasila merupakan suatu sistem politik yang digali dari Pancasila dan Undangundang Dasar 1945. Dan gambaran konsepsi demokrasi Pancasila tersebut, maka tampak dengan jelas bahwa pancasila menjadi jiwa dari demokrasi Indonesia, baik secara formal mekanistik, maupun material normatif.

Dengan demikian, demokrasi sebagai sebuah prinsip dari kehidupan bernegara, memiliki arti penting bagi suatu pembangunan masyarakat dalam suatu negara, sehingga mau tidak mau pilihan terhadap demokrasi adalah sesuatu yang harus diambil untuk dijalankan dalam sistem pemerintahan dan sistem bernegara serta berkehidupan di Indonesia.

\section{Pengertian Konstitusi.}

Secara etimologis, konstitusi adalah segala ketentuan dan aturan mengenai ketatanegaraan (Undang-undang Dasar, dsb), atau Undang-undang Dasar suatu negara. Istilah konstitusi berasal dari bahasa Perancis (constituer) yang berarti membentuk. Pemakaian istilah konstitusi yang dimaksudkan ialah pembentukan snatu negara atau menyusun dan menyatakan suatu negara. Sedangkan istilah Undang-undang Dasar merupakan terjemahan istilah yang dalam bahasa Belanda-nya Gronwet. Perkataan Wet diterjemahkan ke dalam bahasa Indonesia Undang-undang, dan Grond berarti tanah/dasar. ${ }^{43}$

Di Negara-negara yang menggunakan bahasa Inggris sebagai bahasa nasional, dipakai istilah Constitutions yang dalam Bahasa Indonesia disebut konstitusi. Pengertian konsitusi, dalam praktek dapat berarti lebih luas daripada pengertian Undang-undang Dasar. Bagi para sarjana ilmu politik istilah Constitution merupakan sesuatu yang lebih luas, yaitu keseluruhan dari peraturan

${ }^{40}$ Dahlan Thaib, Kedaulatan Rakyat, Negara Hukum dan Konstitusi, Liberty, Yogyakarta, cetakan kedua, 2000, hal 7

${ }^{41}$ Moh. Kusnardi dan Hermaily Ibrahim, Pengantar Hukum Tata Negara Indonesia, PSH Tata Negara FH UI dan

CV. Sinar Bakti, Jakarta, cetakan kelima, 1983, hal 126

${ }^{42}$ Dahlan Thaib, Kedaulatan ..... Op.cit, hal 6-13

${ }^{43}$ Ibid, Hal 7-8 
baik yang tertulis maupun tidak tertulis yang mengatur secara mengikat cara-cara bagaimana sesuatu pemerintahan diselenggarakan dalam suatu masyarakat. ${ }^{44}$

Penyamaan pengertian antara konstitusi dengan Undang-undang Dasar, sebenarnya sudah dimulai sejak Oliver Cromwell (Lord Protector republic Inggris 1649 - 1660) yang menamakan Undang-undang Dasar itu sebagai Instrument of Government, yaitu bahwa Undang-undang Dasar dibuat sebagai pegangan untuk memerintah dan disinilah timbul identifikasi dari pengertian konstitusi dan Undang-undang Dasar. ${ }^{45}$

\section{Kedudukan, Fungsi dan Tujuan Konstitusi}

Kedudukan, fungsi dan tujuan konstitusi dalam negara berubah dari zaman ke zaman. Pada masa peralihan dari negara feudal monarkhi atau oligarkhi dengan kekuasaan mutlak penguasa ke negara nasional demokratis, konstitusi berkedudukan sebagai benteng pemisah antara rakyat dan penguasa yang kemudian secara berangsur-angsur mempunyai fungsi sebagai alat rakyat dalam perjuangan kekusaan melawan golongan penguasa. Sejak itu setelah perjuangan dimenangkan oleh rakyat konstitusi bergeser kedudukan dan perannya dari sekedar penjaga keamanan dan kepentingan hidup rakyat terhadap kezaliman golongan penguasa menjadi senjata pamungkas rakyat untuk mengakhiri kekuasaan sepihak satu golongan dalam sistem monarkhi dan oligarki, serta untuk membangun tata kehidupan baru atas dasar landasan kepentingan bersama rakyat dengan menggunakan berbagai ideologi, seperti individualisme, liberalisme, universalisme dan sebagainya. Selanjutnya kedudukan dan fungsi konstitusi ditentukan oleh ideologi yang melandasi negara. ${ }^{46}$

Di dalam negara-negara yang mendasarkan diri atas demokrasi konstitusional, Undangundang dasar mempunyai fungsi yang khas yaitu membatasi kekuasaan pemerintah sedemikian rupa sehingga penyelenggaraan kekuasaan tidak bersifat sewenang-wenang. Dengan demikian diharapkan hak-hak warga negara akan lebih terlindungi. Gagasan ini dinamakan konstitusionalisme. ${ }^{47}$

Pada prinsipnya tujuan konstitusi adalah untuk membatasi kewenangan tindakan pemerintah, untuk menjamin hak-hak yang diperintah, dan merumuskan pelaksanaan kekuasaan yang berdaulat. Pendapat yang hampir senada disampaikan oleh Loewenstein di dalam bukunya Political Power and the Governmental Proce's, bahwa konstitusi itu suatu sarana dasar untuk mengawasi proses-proses kekuasaan. Oleh karena itu setiap konstitusi senantiasa mempunyai dua tujuan: $^{48}$

a. Untuk memberikan pembatasan dan pengawasan terhadap kekuasaan politik,

b. Untuk membebaskan kekuasaan dari kontrol mutlak para penguasa, serta menetapkan bagi para penguasa tersebut batas-batas kekuasaan mereka.

\section{Hubungan Negara Hukum dengan Konstitusi}

Dalam setiap negara hukum materi hukum itu sendiri biasanya dituangkan dalam bentuk tertulis dengan struktur tertinggi berupa konstitusi yang dikenal dengan Undang-undang Dasar, baik dituangkan dalam dokumen hukum yang tertulis (written constitution) maupun tidak tertulis (unwritten constitution).

Perkembangan konsep negara hukum dalam sistem ketatanegaraan, di mana konsep ini muncul untuk membatasi kekuasaan pemerintah melalui pembuatan konstitusi baik yang tertulis maupun yang yang tidak tertulis. ${ }^{49}$

Loewenstein, Frierich, dan Herman Finer mengatakan bahwa konstitusi merupakan sarana pengendali kekuasaan. Esensi konstitusionalisme minimal terdiri atas dua hal: pertama, konsepsi negara hukum yang menyatakan bahwa secara universal kewibawaan hukum haruslah mengatasi kekuasaan pemerintah yang karenanya hukum harus mampu mengontrol dan mengendalikan politik. kedua, konsepsi hak-hak sipil warga negara yang menggariskan adanya

${ }^{44}$ Ibid, Hal 8

${ }^{45}$ Ibid

${ }^{46}$ Dahlan Thaib, Jazim Hamidi, Ni'matul Huda, Op.cit, hal 19-20

47 Ibid, Hal 21-22

${ }^{48}$ Ibid, Hal 27

${ }^{49}$ Dahlan Thaib, Kedaulatan .....,Op.cit, hal 20 
kebebasan warga negara di bawah jaminan konstitusi sekaligus adanya pembatasan kekuasaan negara yang dasar legitimasinya hanya dapat diperoleh oleh konstitusi. ${ }^{50}$

Pada prinsipnya tujuan konstitusi adalah untuk membatasi kesewenangwenangan tindakan pemerintah, untuk menjamin hak-hak yang diperintah, dan merumuskan pelaksanaan kekuasaan yang berdaulat. Pendapat yang hampir senada disampaikan oleh Loewenstein di dalam bukunya "Political Power and the Governmental Proce's, bahwa konstitusi itu suatu sarana dasar untuk mengawasi proses-proses kekuasaan. Oleh karena itu setiap konstitusi senantiasa mempunyai dua tujuan $:^{51}$

1. Untuk memberikan pembatasan dan pengawasan terhadap kekuasaan politik

2. Untuk membebaskan kekuasaan dari kontrol mutlak para penguasa, serta menetapkan bagi para penguasa tersebut batas-batas kekuasaan mereka.

\section{Kewenangan MPR Melakukan Perubahan UUD a. Sebelum Amandemen UUD 1945}

Sebelum membicarakan tentang kewenangan MPR dalam melakukan perubahan terhadap Undang-undang Dasar 1945, terlebih dahulu perlu diketahui tentang Kedudukan Majelis Permusyawaratan Rakyat. Dalam ketentuan UUD 1945 (sebelum amandemen) MPR merupakan penyelenggara tertinggi yang memegang kedaulatan negara. Majelis ini dianggap sebagai penjelmaan rakyat Indonesia yang memegang kedaulatan negara.

Berkaitan dengan hal ini, Sri Soemantri menyatakan, apabila dikaitkan dengan "the framework or structure of government" yang digunakan oleh Rosco J. Tresolini dan Martin Shapiro, maka konsep kedaulatan rakyat yang dilaksanakan oleh MPR dapat diilustrasikan sebagai berikut: "Bahwa kedaulatan rakyat yang merupakan kedaulatan politik yang dimiliki oleh rakyat dilaksanakan oleh MPR. Lembaga pelaksanaan kedaulatan rakyat ini memiliki otoritas untuk menetapkan UUD yang menimbulkan kedaulatan hukum, yang pada dataran lebih jauh diaktualisasikan oleh presiden bersama DPR di bidang legislasi. Kedaulatan hukum ini menjadi dasar bagi MPR dan lembaga tinggi negara lainnya untuk menyelenggarakan fungsi dan kekuasaan negara sebagai pemegang kedaulatan negara. ${ }^{52}$

Kekuasaan MPR untuk melakukan perubahan terhadap UUD 1945 sebagaimana diatur dalam Batang Tubuh UUD 1945 tentang tata cara perubahan, yakni ketentuan di dalam pasal 37 UUD 1945. Pasal itu berbunyi sebagai berikut :

(1) Untuk mengubah Undang-undang Dasar sekurang-kurangnya 2/3 daripada anggota Majelis Permusyawaratan Rakyat harus hadir.

(2) Putusan diambil dengan persetujuan sekurang-kurangnya $2 / 3$ dari pada jumlah anggota yang hadir.

Berkaitan dengan perubahan UUD, setelah amandemen UUD 1945 kewenangan untuk melakukan hal tersebut masih dipegang oleh MPR. Kewenangan MPR ini terkait dengan prosedur perubahan konstitusi melalui formal amendement ialah perubahan konstitusi secara formal vang diatur dalam Undang-undang Dasar 1945, sebagaimana tercantum dalam ketentuan Pasal 37 UUD 1945. Ada tiga kaidah hukum yang terdapat di dalam pengaturan pasal 37 UUD 1945, yaitu bahwa .53

(1) Pihak yang berwenang mengubah Undang-undang Dasar 1945 ialah Majelis Permusyawaratan Rakyat.

(2) Untuk mengubah Undang-undang Dasar 1945, sidang-sidang Majelis permusyawaratan rakyat harus dihadiri oleh sekurang-kurangnya $2 / 3$ (dua per tiga) dari seluruh anggotanya (quorum).

${ }^{50}$ Moh. Mahfud, MD, Amandemen ...... Op.cit, hal 60-61

51 lbid, Hal 27

52 Sumali, Reduksi Kekuasaan Eksekutif di Bidang Peraturan Pengganti Undang-undang (Perpu), penerbit Universitas Muhammadiyah Malang, Malang, 2002

${ }^{53}$ Sri Soemantri, Undang-undang Dasar 1945 Kedudukan dan Aspek-aspek Perubahannya, Unpad Press, Bandung, cetakan, 2000, hal 11 
(3) Keputusan tentang perubahan Undang-undang Dasar 1945 adalah sah, apabila disetujui oleh sekurang-kurangnya 2/3 (dua per tiga) dari anggota Majelis Permusyawaratan Rakyat yang hadir dan memenuhi quorum.

Berdasarkan pengaturan yang terdapat dalam pasal 37 UUD 1945 (sebelum amandemen) yang menjadi pertanyaan adalah apakah perubahan Undang-undang Dasar 1945 termasuk rigid atau flexible? Sri Soemantri memberikan pandangannya terhadap hal tersebut, di mana seandainya dalam sidang Majelis Permusyawaratan Rakyat, yang menghadiri acara perubahan terhadap Undang-undang Dasar 1945 benar-benar 2/3 (dua per tiga) dari anggota Majelis yang berjumlah 700 orang, maka sidang tersebut dihadiri oleh $2 / 3$ dari 700 orang, yaitu 470 orang anggota (dibulatkan ke atas). Dalam pada itu keputusan Majelis Permusyawaratan Rakyat tentang perubahan tersebut sah, apabila disetujui oleh sekurang-kurangnya 2/3 (dua per tiga) dari anggota Majelis yang hadir. Oleh karena yang hadir berjumlah 470 orang, maka keputusan tentang perubahaan Undang-undang Dasar sah apabila disetujui oleh 2/3 (dua per tiga) dari 470 orang anggota Majelis Permusyawaratan Rakyat yang hadir. Ini berarti bahwa keputusan tentang perubahan Undang-undang Dasar sah apabila disetujui oleh 2/3 x 470 orang, yaitu oleh 313 orang anggota Majelis Permusyawaratan Rakyat. Apabila diperhatikan angka 313, yang menyatakan sahnya keputusan Majelis permusyawaratan rakyat tentang perubahan Undang-undang Dasar, angka tersebut jelas di bawah angka 350, yaitu separuh jumlah anggota Majelis. Ini berarti bahwa walaupun Pasal 37 Undang-undang Dasar 1945 mensyaratkan quorum adalah 2/3 (dua per tiga) dan sahnya keputusan sekurang-kurangnya $2 / 3$ (dua per tiga) dari yang hadir dalam kenyataan dapat terjadi bahwa yang menyetujui perubahan Undang-undang Dasar 1945 hanya 313 orang anggota Majelis. Oleh Karena itu, perlu difikirkan prosedur yang lebih sulit ada beberapa kemungkinan pengaturan prosedur dapat dipilih. Pertama, untuk sahnya sidang-sidang Majelis Permusyawaratan Rakyat tetap berdasarkan sekurang-kurangnya 2/3 (dua per tiga) dari seluruh anggota Majelis. Adapun untuk sahnya keputusan diubah, dari persyaratan sekurang-kurangnya 2/3 (dua per tiga) menjadi sekurang-kurangnya 3/4 (tiga per empat). Apabila alternatif ini dipilih, masih dapat dihasilkan angka keputusan Majelis Permusyawaratan Rakyat sebanyak 352. Kedua, quorum diperberat, yaitu dari sekurang-kurangnya $2 / 3$ (dua per tiga) seluruh anggota Majelis Permusyawaratan Rakyat menjadi seluruh anggota Majelis yang berjumlah 700 orang harus hadir. Ketiga, angka $2 / 3$ (dua per tiga), baik untuk quorum maupun untuk sahnya keputusan tentang perubahan Undang-undang Dasar diubah menjadi masing-masing $3 / 4$ (tiga per empat). ${ }^{54}$

Meskipun MPR memiliki kewenangan untuk mengubah undang-undang dasar 1945, sampai dengan sebelum terjadinya perubahan kewenangan ini tidak pernah dilakukan oleh MPR berdasarkan pada Pasal 37 UUD 1945. Kenyataan yang terjadi, di mana kewenangan MPR untuk melakukan perubahan terhadap UUD sangat dipengaruhi oleh kepentingan kekuasaan yang ada pada masa itu.

Kebulatan tekad anggota Majelis yang akan mempertahankan UUD 1945 tidak berkehendak dan tidak akan melakukan perubahan terhadapnya serta akan melaksanakan secara murni dan konsekuen, seperti yang tercantum dalam Pasal 115 Tap MPR No. 1/MPR/1978 tentang Peraturan Tata Tertib MPR, jelas sangat kontradiktif dengan semangat Pasal 37 UUD 1945 dan terlalu dipaksakan. Tidak pernah ada penjelasan yang dapat diterima akal, mengapa negara akan kacau? Salah satu tugas MPR yang paling pokok adalah menetapkan UUD. Berhubungan dengan itu dapat dimengerti mengapa perintah pertama yang diberikan oleh pembuat UUD kepada MPR hasil pemilihan umum ialah supaya menetapkan UUD sebagaimana tercantum dalam Pasal 3 UUD $1945 .{ }^{55}$

Ketetapan tentang referendum ini, sesuai dengan tuntutan Pasal 3 Tap No. IV/MPR/1983 itu, perlu ditindaklanjuti dengan Undang-undang yang mengaturnya. Oleh karena itu pada tahun 1985 Presiden bersama DPR telah menyepakati sebuah UU tentang Referendum yaitu UU No. 5

\footnotetext{
${ }^{54} \mathrm{Ibid}$, hal 12-13, perlu diketahui bahwa jumlah anggota MPR yang keanggotaannya terdiri dari anggota-anggota DPR berjumlah 1000 (seribu) orang. Adapun paparan yang disampaikan oleh Sri Soemantri terkait dengan jumlah anggota MPR sebanyak 700 orang hanya sebagai sebuah gambaran contoh saja.

${ }^{55}$ Ni'matul Huda, Hukum Tata Negara Kajian Teoritis dan Yuridis dan Yuridis Terhadap Konstitusi Indonesia, PSH FH UII, Yogyakarta, hal 146
} 
tahun 1985. Menurut Pasal 1 UU No. 5 Tahun 1985 Referendum adalah kegiatan untuk meminta pendapat rakyat secara langsung mengenai setuju atau tidak setuju terhadap kehendak MPR untuk mengubah UUD 1945. Sedangkan menurut Pasal 2 Referendum diadakan apabila MPR berkehendak untuk mengubah UUD 1945 sebagaimana dimaksud dalam Ketetapan MPR No. IV/MPR/1983. ${ }^{56}$

Dengan adanya Tap MPR dan UU tentang Referendum tersebut maka cara mengubah UUD 1945 menjadi semakin sulit sebab MPR tidak dapat langsung menggunakan pasal 37 tetapi harus melalui Referendum lebih dulu, kalau berkehendak mengubah UUD 1945. Jika berdasar Referendum tersebut rakyat menyetujui perubahan UUD 1945 maka MPR bisa melakukannya menurut ketentuan Pasal 37 UUD 1945. Tetapi jika ternyata rakyat tidak setuju atas kehendak perubahan itu maka gugurlah kehendak MPR untuk mengubah UUD 1945 selama masa jabatan MPR itu. Selanjutnya menurut Pasal 18 UU No. 5 Tahun 1985 itu rakyat dinyatakan menyetujui kehendak MPR untuk mengubah UUD 1945, apabila hasil Referendum menunjukkan bahwa: ${ }^{57}$

a. Sekurang-kurangnya $90 \%$ dari jumlah pemberi pendapat rakyat yang terdaftar telah menggunakan haknya memberikan pendapat rakyat.

b. Sekurang-kurangnya $90 \%$ dari pemberi pendapat rakyat yang menggunakan haknya tersebut menyatakan setuju terhadap kehendak MPR untuk mengubah UUD 1945.

Akhirnya menjadi kenyataan meskipun secara historis telah disebutkan bahwa UUD 1945 ini bersifat sementara dan secara yuridis adanya jaminan pengaturan bagi kewenangan MPR untuk melakukan perubahan, namun pada masa Orde Baru, dalam Sidang Umum MPR tahun 1973 maupun Sidang-sidang umum berikutnya sampai sidang umum MPR tahun 1998, rupanya dikalangan pengambil keputusan politik (political decision makers) yang 1000 (seribu) orang itu tidak muncul kesadaran hukum dan kemauan politik untuk melakukan pembaharuan atau reformasi konstitusi dengan jalan menerapkan Pasal 3 UUD 1945.

Penjelasan tersebut di atas, sebagaimana juga telah dijelaskan sebelumnya bahwa MPR tidak pernah melakukan perubahan UUD 1945 melalui dasar Pasal 37 UUD 1945. Perubahan terhadap UUD 1945 lebih banyak dirubah melalui suatu prosedur yang berbeda di luar ketentuan yang terdapat dalam Pasal 37 tersebut.

Berkaitan dengan hal tersebut, Sri Soemantri memaparkan dan mengatakan, bahwa pada Sidang Umum Majelis Permusyawaratan Rakyat yang diselenggarakan pada tanggal 12 Maret 1973, MPR telah mengeluarkan ketetapan MPR No. I/MPR/1973 tentang Peraturan Tata Tertib Majelis Permusyawaratan Rakyat. Dalam Pasal 4 ketetapan tersebut, diatur sepuluh macam wewenang. termasuk wewenang untuk mengubah Undang-undang Dasar. Dengan perkataan lain melalui ketetapan tersebut, Majelis Permusyawaratan Rakyat telah merubah Undang-undang Dasar 1945 melalui penambahan wewenang. Dari sembilan wewenang penambahan itu terdapat tiga yang menurut pendapat beliau cukup mendasar, yaitu wewenang $:^{58}$

(1) Memberikan penjelasan yang bersifat penafsiran terhadap putusan-putusan Majelis (antara lain Undang-undang Dasar 1945).

(2) Meminta dari dan menilai pertanggungan jawab (seharusnya "pertanggungjawaban") Presiden tentang pelaksanaan Garis-garis Besar Haluan Negara.

(3) Mencabut mandat dan memberhentikan Presiden dalam masa jabatannya apabila Presiden sungguh-sungguh melanggar Haluan Negara dan/atau Undang-undang Dasar.

Dengan sadar Majelis Permusyawaratan Rakyat telah mengubah Undang-undang Dasar 1945. Hal ini dapat dilihat dari dasar hukum yang digunakan. Dalam dasar hukum pertama dikemukakan Pasal 1 ayat (2), Pasal 2, Pasal 3, Pasal 6 ayat (2) dan Pasal 37 UUD 1945. ${ }^{59}$

Hal yang menjadi persoalan ialah mengapa yang dijadikan wahana untuk mengubah UUD 1945 bentuk hukum Ketetapan Majelis Permusyawaratan Rakyat? Padahal kedudukan Ketetapan Majelis Permusyawaratan Rakyat berada di bahwa Undang-undang Dasar (Tap No. XX/MPR/1966 dan Tap No. III/MPR/2000).

\footnotetext{
${ }^{56}$ Ibid, hal 150.

${ }^{57}$ Ibid

58 Ibid, hal 8

59 Ibid, hal 9
} 
Berdasarkan penjelasan tersebut di atas dapat diketahui bahwa Majelis Permusyawaratan Rakyat tidak pernah menggunakan kewenangannya untuk mengubah UUD 1945 dengan menggunakan prosedur sebagaimana diatur dalam ketentuan pasal 37 UUD 1945, akan tetapi MPR telah melakukan perubahan terhadap UUD 1945 berdasarkan pada ketentuan hukum vang memiliki derajat pada tingkat bawah yaitu Ketetapan MPR. Hal ini tentu memberikan kemungkinan dan peluang bagi kekuasaan-kekuasaan yang otoritarian dan tidak konstitusional.

\section{b. Setelah amandemen UUD 1945}

Pada waktu pendiri Negara (the founding fathers and Mothers) sedang mempersiapkan sebuah undang-undang dasar, hampir saja masalah perubahan Undang-undang Dasar terlepas dari pembahasan. Untunglah, salah seorang anggotanya, yaitu Mr. Iwa Koesoemasoemantri mengajukan usul agar dalam Undang-undang Dasar yang akan dibuat itu dicantumkan sebuah pasal yang memungkinkan konstitusi itu diubah. Alasan yang dikemukakan memang kuat. Seperti diketahui, Undang-undang Dasar atau konstitusi adalah buatan manusia yang tidak terlepas dari suasana ketika hal itu ditetapkan. Walaupun konstitusi tersebut direncanakan untuk berlaku jauh ke depan, akan tetapi seiring perkembangan ilmu pengetahuan dan teknologi, sosial-budaya, dan lain-lain ada kemungkinan beberapa pasal yang tercantum dalam konstitusi tidak sesuai lagi dengan perkembangan masyarakat. Itulah yang menjadi alasan adanya Pasal 37 Undang-undang Dasar $1945 .^{60}$

Mengapa UUD 1945 diamandemen? Jawaban elementernya atau argumentasi orang awam atas pertanyaan itu barangkali karena ternyata dengan UUD 1945 praktik penyelenggaraan kehidupan berbangsa dan bernegara selalu melahirkan pemerintahan yang otoriter, korup, dan tidak demokratis. Meskipun syarat terbentuknya pemerintahan yang merakyat, bersih dan demokratis tidak hanya ditentukan oleh konstitusinya. Argumentasi di atas sebetulnya cukup beralasan, dengan asumsi karena konstitusi itu bersih hukum-hukum dasar, prinsip-prinsip dasar dalam penyelenggaraan bernegara, serta hendak ke mana tujuan bernegara itu akan dilabuhkan. ${ }^{61}$

Secara sepintas UUD 1945 telah mengatur seruan paham konstitusi yaitu anatomi kekuasaan tunduk pada hukum (supremasi hukum), adanya jaminan dan perlindungan atas hakhak asasi manusia, adanya prinsip peradilan yang bebas, dan menganut atas kedaulatan rakyat. Namun dalam kenyataannya, prinsip-prinsip tersebut belum dikolaborasikan secara proporsional dalam praktik ketatanegaraan di Indonesia baik pada masa Orde Lama, Orde Baru, dan di "Orde Reformasi". Atau kalaulah sudah diterapkan dalam tataran riil, tetapi masih belum menyentuh substansinya. ${ }^{62}$

Atas dasar argumentasi di atas, dapatlah dikatakan bahwa UUD 1945 itu diamandemen karena ruh dan pelaksanaan konstitusinya jauh dari paham konstitusi itu sendiri. Hal ini sejalan bahkan diperkokoh oleh hasil Tim Kajian Amandemen Fakultas Hukum Unibraw yang mencoba mengklasifikasi beberapa kelemahan UUD 1945, antara lain: UUD 1945 telah memposisikan kekuasaan Presiden begitu besar (executive power), sistem check and balances tidak diatur secara tegas di dalamnya, ketentuan UUD 1945 banyak yang tidak jelas dan multi tafsir, tentang minimnya pengaturan masalah hak-hak asasi manusia, sistem kepresidenan dan sistem perekononiian yang kurang jelas. ${ }^{63}$

Alasan lain yang dapat dijadikan dasar pertimbangan perlunya mengamandemen UUD 1945, karena secara historis UUD 1945 memang didisain oleh para pendiri negara sebagai konsitusi yang bersifat sementara dan ditetapkan dalam suasana tergesa-gesa. Secara filosofis, ide dasar dan substansi UUD 1945 telah mencampur adukkan antar paham kedaulatan rakyat dengan paham integralisitik. Padahal antara keduanya bertolak belakang, bahkan paham integralistiklah yang telah memberangus demokratisasi di Indonesia. Kemudian secara yuridis, karena UUD 1945 sendiri telah mengatur prinsip dan mekanisme perubahan konstitusi (Pasal 37). Adapun dasar

\footnotetext{
${ }^{60}$ Sri Soemantri, Op.cit, hal 9-10

${ }^{61}$ Dahlan Thaib, Jazim Hamidi, Ni'matul Huda, Teori dan Hukum Konstitusi, PT. Raja Grafindo, Jakarta, 2001, hal 169

${ }^{62}$ Ibid, hal 170

63 Ibid, 170-171
} 
pertimbangan praktis politisnya sesuai dengan sinyalemen Mochtar Prabottinggi bahwa konstitusi/UUD 1945-nya sudah lama tidak dijalankan secara murni dan konsekuen. ${ }^{64}$

Sejak berlakunya Undang-undang Dasar 1945, baik pada periode pertama, antara 1945 sampai 1949, maupun pada periode kedua, setelah tanggal 5 Juli 1959, secara formal konstitusional, Undang-undang Dasar tersebut belum pernah diubah. Kalau ternyata ada yang berubah, perubahan tersebut tidak sepenuhnya melalui Pasal 37 Undang-undang Dasar $1945 .{ }^{65}$

Setelah 54 tahun, baru pada Sidang Umum MPR 1999, UUD 194 dapat diubah dengan perubahan pertama pada Sidang Umum MPR tanggal 14 sampai dengan 21 Oktober 1999, Perubahan kedua yang dilaksanakan dalam Sidang Tahunan MPR tanggal 7 sampai dengan 18 Agustus 2000, perubahan ketiga dalam Sidang Tahunan MPR tanggal 1 sampai dengan 9 November 2001, dan perubahan keempat yang dilaksanakan pada Sidang Tahunan MPR tanggal 1 sampai 11 Agustus 2002. Dengan adanya empat kali perubahan terhadap UUD 1945 menandakan bahwa proses perubahan ketatanegaraan Indonesia telah berlangsung dan direspon secara langsung melalui pengagendaan Sidang Tahunan MPR.

Ketetapan Majelis Permusyawaratan Rakyat Republik Indonesia No. XI/MPR/2001 tentang perubahan atas ketetapan Majelis Permusyawaratan Rakyat Republik Indonesia No. IX/MPR/2000 tentang Penugasan Badan Pekerja Majelis Permusyawaratan Rakyat Republik Indonesia untuk mempersiapkan rancangan Perubahan Undang-undang Dasar Negara Republik Indonesia Tahun 1945. Dalam pasal 1 ketetapan tersebut ditentukan :

"Dalam rangka melaksanakan tugas seperti yang dimaksudkan pada pasal 1, badan pekerja Majelis Permusyawaratan Rakyat Republik Indonesia menggunakan materi rancangan perubahan Undang-undang Dasar negara RepubliK Indonesia tahun 1945 sebagaimana dimuat dalam lampiran yang menjadi bagian tak terpisahkan dari ketentuan ini”.

Perlu diketahui bahwa kedudukan MPR setelah amandemen UUD 1945 adalah sebagai lembaga permusyawaratan yang keanggotaannya terdiri dari DPR dan DPD. Dalam hal ini MPR bukan lagi sebagai lembaga tertinggi negara dan juga tidak lagi memegang kedaulatan rakyat sebagaimana diatur dalam ketentuan UUD 1945 sebelum amandemen. Sebagaimana disebutkan dalam pasal 1 ayat (2) amandemen UUD 194 bahwa "kedaulatan berada ditangan rakyat dan dijalankan sepenuhnya menurut UUD". Dalam hal ini terjadi perubahan dalam sistem ketatanegaraan Indonesia yang mengatur mengenai kedudukan lembaga-lembaga negara.

Perubahan keempat UUD 1945 pada tanggal 10 Agustus 2002, di mana terhadap ketentuan Pasal 37 Undang-undang Dasar mengenai perubahan UUD yang telah disepakati oleh Badan Pekerja Majelis Permusyawaratan Rakyat Republik Indonesia seluruhnya sebagai berikut :

(1) Usul perubahan pasal-pasal Undang-undang Dasar dapat diagendakan dalam sidang Mejelis Permusyawaratan Rakyat apabila diajukan oleh sekurang-kurangnya 1/3 dari jumlah anggota Majelis Permusyawaratan Rakyat.

(2) Setiap usul perubahan pasal-pasal Undang-undang Dasar diajukan secara tertulis dan ditunjukkan dengan jelas bagian yang diusulkan untuk diubah beserta alasannya.

(3) Untuk mengubah pasal-pasal Undang-undang Dasar, sidang Majelis Permusyawaratan Rakyat dihadiri oleh sekurang-kurangnya $2 / 3$ dan jumlah anggota Majelis Permusyawaratan Rakyat.

(4) Putusan untuk mengubah pasal-pasal Undang-undang Dasar dilakukan dengan persetujuan sekurang-kurangnya lima puluh person ditambah satu anggota dari seluruh anggota Majelis Permusyawaratan Rakyat.

(5) Khusus tentang bentuk Negara Kesatuan Republik Indonesia tidak dapat dilakukan perubahan.

Dalam ayat (1) diatur tentang usul perubahan UUD 1945. Untuk dapat diagendakan dalam sidang, usul perubahan harus diajukan oleh sekurang-kurangnya 1/3 (satu per tiga) dari jumlah anggota Majelis Permusyawaratan Rakyat. MPR yang terdiri dari DPR dan DPD dengan demikian jumlah anggota MPR adalah merupakan gabungan dari anggota DPR dan DPD. Adapun jumlah

\footnotetext{
${ }^{64} \mathrm{lbid}$, hal 171

${ }^{65}$ Sri Soemantri, Op.cit, hal 5
} 
anggota DPR adalah 550 orang dan DPD jumlah anggotanya 183 orang (1/3 dari jumlah anggota DPR). Dengan demikian jumlah anggota MPR adalah 733 orang. Dengan jumlah anggota MPR yang sebanyak 733 (tujuh ratus tiga puluh tiga) orang hal ini berarti 1/3 (satu per tiga) dari 733 , sama dengan 244,3 orang. Dengan perkataan lain perubahan. Undang-undang Dasar diagendakan, apabila diusulkan oleh sekurang-kurangnya 244 orang (dibulatkan) anggota Majelis Permusyawaratan Rakyat.

Undang-undang Dasar 1945 telah empat kali diubah. Seperti yang diketahui, pada waktu akan diadakan perubahan (yang pertama), Majelis Permusyawaratan Rakyat telah membentuk sebuah Badan Pekerja. Untuk merencanakan perubahan Undang-undang Dasar itu Badan Pekerja telah membentuk Panitia Ad Hoc I. Panitia Ad Hoc I telah mengagendakan pertemuan dengan berbagai pihak, diantaranya dengan para pakar. Rencana perubahan yang telah dilakukan oleh Panitia Ad Hoc I itu kemudian dibahas dalam Badan Pekerja Majelis Permusyawaratan Rakyat. Keputusan Badan Pekerja tersebut kemungkinan menghasilkan kesepakatan tentang substansi yang akan diubah, dan dapat pula terjadi adanya berbagai alternatif tentang substansi yang akan diubah. Hasil yang telah diputuskan oleh Badan Pekerja Majelis Permusyawaratan tersebut kemudian dilampirkan kepada (sidang paripurna) Majelis Permusyawaratan Rakyat. ${ }^{66}$

Setelah diadakan pemandangan umum, akhirnya Rancangan perubahan Undang-undang Dasar beserta berbagai masalah yang dikemukakan dalam pemandangan umum tersebut diteruskan kepada Komisi A, yang oleh sidang diberi tugas membahas rancangan perubahan Undang-undang Dasar. Keputusan Komisi A dapat berupa kesepakatan tentang substansi vang diubah, dan dapat pula berbentuk berbagai alternatif perubahan. Keputusan yang telah diambil oleh Komisi A tersebut kemudian diteruskan kepada Sidang Paripurna Majelis Permusyawaratan Rakyat untuk ditetapkan sebagai keputusan perubahan yang final ${ }^{67}$

Terhadap mekanisme ini ada usulan agar Majelis Permusyawaratan Rakyat membentuk sebuah komisi konstitusi yang diberi tugas khusus mempersiapkan perubahan Undang-undang Dasar secara menyeluruh. Artinya, setelah perubahan secara menyeluruh itu ditetapkan oleh Majelis Permusyawaratan Rakyat, jangan lagi dilakukan perubahan Undang-undang Dasar dalam Sidang Tahunan Majelis Permusyawaratan Rakyat. ${ }^{68}$

Terhadap usulan pembentukan Komisi Konstitusi ini kemudian Majelis Permusyawaratan Rakyat mengeluarkan Ketetapan Nomor 1/MPR/2002 tentang Pembentukan Komisi Konstitusi. Dalam konsideran ketetapan Majelis ini disebutkan, bahwa berdasarkan pertimbangan di atas, dipandang perlu membentuk suatu Komisi Konstitusi yang bertugas melakukan pengkajian secara komprehensif tentang perubahan Undang-undang Dasar Negara Republik Indonesia Tahun 1945.

Itulah sebabnya ada usulan agar Majelis Permusyawaratan Rakyat membentuk sebuah Komisi Konstitusi yang dapat bekerja dengan tenang dan secara mendalam untuk jangka waktu dua sampai tiga tahun. Ada berbagai kemungkinan tentang anggota-anggotanya. Artinya, dapat juga seluruh anggotanya ialah para anggota Majelis Permusyawaratan Rakyat dengan didampingi para pakar dalam berbagai bidang ilmu, dan dapat pula anggota-anggotanya merupakan campuran dari berbagai kelompok yang ada dalam masyarakat. Namun, perlu diperhatikan bahwa keputusan terakhir harus tetap berada di tangan Majelis Permusyawaratan Rakyat. ${ }^{69}$

Kalau kita bandingkan dengan Perubahan Undang-undang Dasar 1945 terhadap Pasal 37 tersebut jauh lebih lengkap dibandingkan dengan pasal perubahan Undang-undang Dasar 1945 (sebelum amandemen). Kelengkapan dari UUD 1945 hasil amandemen ini terlihat dari adanya jumlah pengaturan ayat-ayat yang terdapat tiap-tiap pasal, meskipun jumlah pasal yangy terdapat dalam UUD 1945 (sebelum amandemen) masih lama dengan UUU 1945 (amandemen).

6. Hubungan antara Kewenangan MPR untuk Melakukan Perubahan UUD dengan Kedaulatan Rakyat

Berkaitan dengan hal tersebut, Majelis Permusyawaratan Rakyat sebagai sebuah lembaga yang mengaktualisasikan dan merepresentasikan nilai-nalai kedaulatan rakyat dalam kewenangan

\footnotetext{
${ }^{66}$ Ibid, hal 16

${ }^{67}$ Ibid, hal 16-17

68 Ibid, hal 17

${ }^{69}$ Ibid, hal 18
} 
yang dimilikinya yaitu dalam hal perubahan UUD 1945, dituntut untuk memiliki visi dan kekuatan untuk mewujudkan cita-cita nasional bangsa dan rakyat Indonesia. Semua ini karena lembaga ini terbentuk atas dasar limpahan kekuasaan yang semula dimiliki oleh rakyat melalui pemilihan umum. Limpahan dari rakyat kepada alat-alat perlengkapan negara termasuk dalam hal ini adalah MPR, wajib untuk memainkan tugas dan fungsinya secara baik.

Konstitusi merupakan sebuah produk politik. Meskipun terhadap hal tersebut tidak dipungkiri karena yang membuat substansi dari materi konstitusi (UUD) dalam hal ini adalah Majelis Permusyawaratan Rakyat. Seringkali dalam realitas yang terjadi dalam pembuatan UUD 1945 unsur-unsur kepentingan politik lebih kental daripada maksud dan tujuan dari sebuah UUD itu diadakan. Makna pembatasan kekuasaan oleh konstitusi terkadang tidak berjalan dengan baik karena pengaturan yang terdapat dalam UUD tersebut memang tidak memberikan pengaturan atau kurang memberikan pengaturan yang layak dan representatif.

Hal ini menurut penulis, karena terdapatnya unsur kepentingan politik yang termuat dalam pembuatan konstitusi. Norma hukum yang tercantum dalam UUD 1945 terkadang pada satu sisi hanya merupakan landasan formalitas saja, akan tetapi kepentingan politik lebih mewarnai ketimbang faktor kesadaran hukum. Meskipun hal ini hanya berlaku mungkin untuk beberapa pasal saja. Hal inilah yang memberikan sedikit gambaran bahwa proses politik menjembatani upaya perubahan UUD 1945, di mana substansinya tidak mungkin terlepas dari faktor kepentingan politik, tanpa harus memberikan suatu gambaran sebagaimana yang terjadi pada praktek penyelenggaraan ketatanegaraan yang terjadi di Indonesia pada waktu-waktu sebelumnya.

Hubungan antara kewenangan yang dimiliki oleh MPR dengan kedaulatan rakyat adalah nilai normatif sebagai pengikat dari konstitusi di mana konstitusi yang dibuat oleh MPR, dijadikan sebagai pedoman dalam melakukan aktivitas ketatanegaraan oleh penguasa dan rakyat. Oleh karena itu, maka diharapkan agar MPR dalam merumuskan dan membuat UUD 1945 harus mengambil suatu kebijakan yang berdasarkan atas prinsip-prinsip demokrasi dan prinsip hukum, sehingga nilai kedaulatan rakyat dapat terlihat dalam hasil pembuatan UUD oleh MPR. Dalam penelitian ini tidak dibahas secara mendetail mengenai substansi pengaturan yang terdapat dalam pasal-pasal UUD 1945 setelah diamandemen, namun hanya beberapa pasal saja yang dijadikan contoh sebagai penegas dan penjelas dari pemaparan.

Kalau kita lihat pengaturan yang terdapat dalam UUD 1945 sebelum diamandemen, beberapa pasal-pasal yang terdapat di dalamnya memberikan adanya suatu multi tafsir dari penguasa sehingga seringkali dijadikan sebagai bahan legitimasi bagi kekuasaannya. Tidak adanya kejelasan yang terdapat dalam pasal-pasal UUD 1945 ini mengakibatkan tidak berjalannya nilai-nilai kedaulatan rakyat. Tidak berjalannya nilai kedaulatan rakyat karena beberapa hal tentang hak asasi manusia misalnya tidak ada dalam materi muatan UUD 1945 sebelum amandemen.

Sedangkan kalau dilihat dari perubahan UUD 1945 pada masa sekarang, memberikan kemungkinan terjadinya beberapa kali perubahan. Seandainya sistem politik yang berlangsung di Indonesia berjalan dengan stabil maka bisa dipastikan bahwa perubahan-perubahan yang akan berlangsung kemudian merupakan sebuah jawaban atas kebutuhan yang diinginkan oleh masyarakat.

Kebutuhan terhadap hukum yang representatif dan layak bagi kesejahteraan masyarakat merupakan kebutuhan yang penting untuk segera diwujudkan. Pemenuhan atas kesejahteraan masyarakat merupakan salah satu fungsi penting dari hukum itu sendiri.

Dalam pada itu hukum dalam pembangunan mempunyai empat fungsi, sebagai berikut : ${ }^{70}$

1. Hukum sebagai pemeliharaan ketertiban dan keamanan

2. Hukum sebagai sarana pembangunan

3. Hukum sebagai sarana penegak keadilan

4. Hukum sebagai sarana pendidikan masyarakat.

Dari keempat fungsi hukum tersebut diharapkan konstitusi sebagai salah satu bagian dari produk dapat membentuk dan mewujudkan fungsi hukum sebagaimana disebutkan di atas. Oleh

${ }^{70}$ CFG. Sunaryati Hartono, Hukum Ekonomi Pembangunan Indonesia, CV. Trimitra Mandiri, Jakarta, cetakan ketiga, 1999 , hal 10 
karena itu, MPR dalam hal ini yang berwenang untuk merubah UUD 1945 diharapkan dalam materi muatan konstitusi yang dirubahnya dapat mendalilkan hal ini dalam suatu konsep UUD 1945.

Selain itu hubungan antara kewenangan MPR dengan kedaulatan rakyat tercermin dalam segi muatan materi konstitusi yaitu perlindungan HAM dan warga negara, susunan ketatanegaraan suatu negara yang mendasar, dan pembatasan dan pembagian tugas-tugas ketatanegaraan yang mendasar. Ketiga hal ini merupakan materi dasar sebagai persyaratan dari adanya kontitusi. Apabila hal ini tidak ada maka konstitusi itu tidak bisa dikatakan sebagai sebuah aturan dasar yang lengkap. Jaminan atas terbentuknya dan tertuangkannya ketiga hal ini dalam sebuah konstitusi merupakan jalan bagi lahirnya kedaulatan rakyat dalam sebuah negara.

Berkaitan dengan hal tersebut di atas, Jimly Ashiddiqie mengemukakan, kekuasaan kenegaraan dalam wadah Negara Kesatuan Republik Indonesia pada pokoknya adalah derivat dari kesadaran kolektif mengenai Kemahakuasaan Tuhan Yang Maha Esa. Keyakinan akan Kemahakuasaan Tuhan itu diwujudkan dalam paham kedaulatan hukum dan sekaligus dalam kedaulatan rakyat yang diterima sebagai dasar-dasar berpikir sistemik dalam konstruksi UUD negara kita. Prinsip kedaulatan hukum diwjudkan dalam gagasan 'rechtsstaat' atau 'the rule of law' serta prinsip supremasi hukum yang selalu kita dengung-dengungkan setiap waktu. Namun dalam perwujudannya, perumusan hukum yang dijadikan pegangan tertinggi itu haruslah disusun sedemikian rupa melalui mekanisme demokrasi yang lazim sesuai dengan sila kerakyatan yang dipimpin oleh hikmat kebijaksanaan dalam permusyawaratan/perwakilan. Sebaliknya, konsep kedaulatan rakyat diwujudkan melalui instrumen-instrumen hukum dan sistem kelembagaan negara dan pemerintah sebagai institusi hukum yang tertib. Karena itu, produk hukum yang dihasilkan selain mencerminkan prinsip Ketuhanan Yang Maha Esa, juga haruslah mencerminkan perwujudan prinsip kedaulatan rakyat. Setiap produk hukum dihasilkan tidak boleh bertentangan dengan cita Ketuhanan Bangsa Indonsia yang dijamin dalam Pancasila tetapi produk hukum tersebut bukanlah penjelmaan langsung dari keyakinan-keyakinan ummat beragama terhadap hukum-hukum ilahiyah. Proses terbentuknya hukum nasional yang disepakati itu haruslah melalui proses permusyawaratan sesuai prinsip demokrasi perwakilan sebagai pengewajantahan prinsip kedaulatan rakyat. Oleh karena itu, prinsip kedaulatan rakyat itu selain diwujudkan dalam bentuk peraturan perundang-undangan yang akan dihasilkannya, juga tercemin dalam struktur dan mekanisme kelembagaan pemerintah yang menjadi tegaknya sistem hukum dan berfungsinya sistem demokrasi. ${ }^{71}$

Oleh karena itu, sebagai sebuah lembaga politik yang pada prinsipnya diamanatkan untuk melaksanakan kedaulatan rakyat diharapkan dapat seminimal mungkin menghindari terjadi kecendrungan untuk lebih mengutamakan kepentingan politik segolongan kelompok di bandingkan dengan kepentingan rakyat Indonesia. Keberhasilan sebuah tujuan masyarakat sebagaimana nyatakan secara tegas dalam pembukaan UUD 1945 untuk membentuk suatu tatanan masyarakat yang adil dan makmur adalah tujuan utama yang harus menjadi prioritas penting dari lembaga politik yang bernama Majelis Permusyawaratan Rakyat tersebut.

\section{Penutup}

1. Kesimpulan

Dari hasil penelitian dan setelah dilakukan pembahasan dari bab bab yang ada, maka dapat disimpulkan bahwa:

1. Kewenangan MPR untuk melakukan perubahan Undang-undang Dasar di Indonesia sebelum dan sesudah amandemen UUD 1945, di mana pada waktu perubahan terhadap UUD 1945 berdasarkan pengaturan UUD yang lama sebenarnya tidak terlalu rigid (sulit). Akan tetapi karena adanya faktor politik kepentingan yang membungkus kewenangan MPR ini menjadi mandul dan tidak pernah dilaksanakan berdasarkan Pasal 37 UUD 1945. Sedangkan dalam hal perubahan UUD 1945 berdasarkan pada ketentuan UUD yang baru, dalam hal pengusulan perubahan memang tidak terlampau sulit (rigid), akan tetapi ketika sampai pada masa

71 Jimly Asshiddiqie, Format Kelembagaan Negara dan Pergeseran Kekuasaan Dalam UUD 1945, FH UII Press, Yogyakarta, 2004, hal 10-11 
pengambilan keputusan dapat dikatakan rigid (sulit) karena harus dihadiri oleh semua anggota MPR.

2. Hubungan antara kewenangan MPR untuk melakukan perubahan UUD dengan kedaulatan rakyat di mana hal ini ditentukan oleh substansi materi yang dituangkan oleh MPR dalam konstitusi yang dirubah. Apabila materi muatan dari UUD 1945 yang dirubah oleh MPR memenuhi persyaratan-persyaratan diantaranya tentang perlindungan HAM, susunan ketatanegaraan dan pembatasan serta pembagian kekuasaan di atur maka dapatlah kiranya nilai kedaulatan rakyat dapat terjalin di dalamnya.

\section{Saran-saran}

1. Dalam melakukan perubahan terhadap UUD 1945 dibutuhkan tenaga ahli yang terdiri dari para pakar dari berbagai disiplin ilmu pengetahuan agar nanti subtansi materi yang hendak disusun oleh MPR dapat memiliki kualitas nilai yang mencerminkan kedaulatan rakyat.

2. Perlu adanya pengkajian tersendiri dari sebuah komisi yang khusus mengkaji masalah UUD seperti Komisi Konstitusi agar sekiranya dalam pembuatan UUD tidak terkesan tergesa-gesa, sehingga benar-benar dalam pengambilan kebijakan tentang perumusan UUD representasi rakyat yang diemban oleh lembaga ini dapat tercemin di dalamnya.

3. Kewenangan yang dimiliki oleh MPR setelah adanya perubahan UUD 1945, di mana terdapat dua lembaga perwakilan yang merupakan bagian anggota dari MPR dapat memiliki suatu inisiatif yang cemerlang untuk mengusulkan perubahan UUD berdasarkan kebutuhan rakyat dalam upaya meningkatkan kesejahteraan rakyat.

4. Perlu adanya kesadaran politik dari anggota-anggota MPR dalam melakukan perubahan UUD 1945, dengan tidak mengedepankan visi politik sebagai ujung tombak dalam melakukan perubahan UUD 1945.

5. Perlu adanya pelibatan dari masyarakat secara partisipatif dalam mengajukan usul-usul perubahan terhadap UUD sehingga mampu menjadi bahan pertimbangan tersendiri bagi MPR dalam menelurkan kebijakan-kebijakan yang berkaitan dengan sistem ketatanegaraan pada masa yang akan datang.

\section{DAFTAR PUSTAKA}

\section{LITERATUR}

Azhary, Negara Hukum Indonesia, AnalisisYuridisNormatiftentangUnsur-unsurnya, UI Press, Jakarta, 1995

CFG.Sunaryati Hartono, HukumEkonomi Pembangunan Indonesia, CV. TrimitraMandiri, Jakarta, cetakanketiga, 1999

DahlanThaib, ImplementasiSistemKetatanegaraanMenurut UUD 1945, Liberty, Yogyakarta, 1993

DahlanThaib, JazimHamidi, Ni'matul Huda, TeoridanHukumKonstitusi, PT. Raja Grafindo, Jakarta, 2001

DahlanThaib, Kedaulatan Rakyat, Negara HukumdanKonstitusi, Liberty, Yogyakarta, cetakankedua, 2000

DahlanThaib, PancasilaYuridisKetatanegaraan, AMP YKPN, Yogyakarta, 1991

David Beethamdan Kevin Boyle, Introducing Democracy: 80 Question and Answer, (penerjemah) Bern. Hidayat, Demokrasi 80 Tanya Jawab, Kanisius, Yogyakarta, 2000

JimlyAsshiddiqie, Format Kelembagaan Negara danPergeseranKekuasaanDalam UUD 1945, FH UII Press, Yogyakarta, 2004

Johnny Ibrahim, Teori\&MetodePenelitianHukumNormatif, Banyumedia Publishing, Malang 2006

K.C. Wheare. Modern Constitution, (penerjemah) Muhammad Hardani, Konstitusi-konstitusi Modern,cetakanpertama, Pustaka Eureka, Surabaya, 2003

Moh.Kusnardi dan Bintan Saragih, Ilmu Negara, Gaya Media Pratama, Jakarta, 1988

Moh.KusnardidanHermaily Ibrahim, PengantarHukum Tata Negara Indonesia, PSH Tata Negara FH UI dan CV. SinarBakti, Jakarta, cetakankelima, 1983 
Moh.Mahfud, MD, Hukum dan Pilar-pilar Demokrasi, Gama Media, Yogyakarta, 1999

Moh.Mahfud, MD, Amandemen Konstitusi Menuju Reformasi Tata Negara, UII Press, Yogyakarta, 1999

Moh.Mahfud, MD, Dasar dan Struktur Ketatanegaraan Indonesia, UII Press, Yogyakarta, 1993

Ni'matul Huda, Hukum Tata Negara KajianTeoritisdanYuridisterhadapKonstitusi Indonesia, PSH FH UII, Yogyakarta, cetakanpertama, 1999

Peter Mahmud Marzuki. PenelitianHukum. Universitas Air Langga. Surabaya.

Sri Soemantri M, UUD 1945 KedudukandanAspek-aspekPerubahannya, Unpad Press, Bandung, 2002

Sri Soemantri, Undang-undangDasar 1945 KedudukandanAspek-aspekPerubahannya, Unpad Press, Bandung, cetakan, 2000

Sumali, ReduksiKekuasaanEksekutif di BidangPeraturanPenggantiUndang-undang (Perpu), PenerbitanUniversitasMuhammadiyah Malang, Malang, cetakanpertama, 2002

\section{PERATURAN PERUNDANG-UNDANGAN}

Undang Undang Dasar 1945

Undang-undangNomor 22 Tahun 2003 tentangSusunandanKedudukan MPR, DPR, 